\title{
Pages from the Textbook of Alternate History: Columbus Discovers Asia
}

Accounts from the early exploration of Asia suggest that its principal discoverer, Christopher Columbus, had secretly imagined something different from what he had proposed to Ferdinand and Isabella. Though he had applied for a charter, and sponsorship, for the purpose of reaching China by a Western sea route-the feat for which he is known to history-from his private journal historians conclude that he hoped to discover an imaginary Atlantis resting between the continents, that he called by the name of America, which etymology we now believe derives from the Italian Amare Cane, or dog-love.

The following account was written by Bartolome de las Casas, the grandson of Francisco de las Casas, who accompanied Columbus on that first voyage.

There was no America. Only the Atlantic. A flat, blue surface folding over itself. No savages to subdue. No gold to mine. No islands of paradise, even. Columbus was chagrined by the ocean's emptiness. A great undiscovered continent was something he had imagined, and now all that was left for him to do was proceed toward the relative banality of Asia. But there would be gold and savages there, too, he told himself.

How bitter, though, that the prehistoric country of his dreams, and the future he imagined there, could never be. A New Europe, a fresh start for her people, and the continuance of his great voyage pushing west across the earth for hundreds of years without ever reaching its limit.

Columbus was not alone. Adventurous men traveled with him, men who had at times entertained thoughts of mutiny-not against their captains, not against the crown-but against Columbus himself. Yet, as long as the rations held, he did not suffer insurrection, only ennui. For many days Columbus looked down at the surf 
crashing against the hull of the ship, speckled white, like a thirsty tongue. Occasionally, while staring into the water, Columbus would find himself feeling philosophical, and engage his fellow travelers with his pensées.

It was one such day. The Santa Maria, flanked by her two sisters, sailed headlong into the skyline. Another rotation of the sun had brought that nuclear light down to the horizon, and they coasted slowly toward it. Venus appeared like a mole in the sky's complexion, low and to the left, then suddenly all the stars emerged like a pox.

"Francisco," Columbus called to a mate, who stood only a few feet away toward the bow. "Why do you think, when the sun sets, the blue fades away from the water?"

"Water is reflective, like glass," Francisco said. "It looks blue to you because the sky is blue. Only when there is no light being reflected on it can you see its true color."

"But if there is no light, Francisco, then you can't see anything. It is just black."

Francisco nodded. "Wine-dark, sir, is what Homer called it."

On the morning of the seventh day of the third month after the voyagers' departure, the Santa Maria suddenly lurched and stalled, groaning with the burden of its weight, followed by the Pinta, then the Nina. No one had sighted land.

"Did any one drop anchor?" Columbus called out. "Has any one gone adrift?" The admiral, when he arrived at his senses, answered that no man or anchor had been cast off.

Craning his neck over the bow, a lookout announced, "We've touched land!" But when Columbus looked out he saw nothing.

"A sandbar," Francisco clarified.

"Then land must be near," said the admiral, soberly, not wishing to excite the crew too much.

"Or the mountain ranges of some buried world," said Columbus, still dreaming.

When it turned out not to be an indication of land, nor the peak of some Atlantean wonder, the seamen had no other course but to extricate the ships from the ridge, by means of shifting all the weight to the bow, since they had already passed over a good part of the border, and raising their masts high to the wind. Turning their heads to where the ship left its wake, the men could see the 
sandbar stretching out like a seawall far to the north and the south, as if splitting the ocean in two.

"Has the Nina suffered any?" Columbus asked Francisco, who had started inspecting the Santa Maria for wood rot.

Rather than reply, Francisco handed Columbus the awl with which he had been testing the frame. "Why don't you go make sure the crew is safe?"

Columbus wondered if he should have had the admiral punish his insubordinate shipmate, for the sake of a well-ordered voyage, but decided instead to go into his stateroom and tinker with his astrolabe.

When the Santa Maria finally arrived in Shanghai, the admiral raised the royal standard, and the other two ships bore the green cross with the insignia of the king and queen. All the necessary declarations were made, and a few heathens were brought on board to be studied. These specimens were mere villagers and had none of the ornament or riches that had been described in The Travels of Marco Polo. Somewhat disappointed, Columbus declared that, since the people of this country were not as Marco Polo had specified, then they must not be true Chinese. He ordered them detained and sent back to the kingdom for examination. Their poverty was disconcerting to Columbus, since the royal coffers were depleted, and rations were becoming scarce. Then he, Francisco, and the comptroller who had been appointed by the crown all stepped out onto land, where fog moved downwind toward Portugal.

Walking through the streets of Shanghai, beside horses and wagons drawn along on grooved paths, Columbus, Francisco, and the comptroller drew impolite stares and laughter. To the townsmen, they appeared funnily stretched, gangly-armed like monkeys, and ungracefully tall. They were unclean as only seamen can be, and even fishmongers held their noses as they passed.

Columbus approached a group of savages and attempted to barter broken bits of ceramic and glass for some pomegranates, but the merchant only stared vacantly at the fragments with which he was presented. The comptroller suggested to Columbus that there was perhaps a language barrier that had obscured his intentions.

When another customer squeezed in past them and laid down a slip of decorated paper, he walked away with a dozen or so pear-shaped 
fruit. Columbus was incredulous. Why did this merchant accept this useless bit of ornate parchment, covered with ink, while he wanted none of the treasures that they had brought from across the ocean? The merchant tucked his earnings away in a box with a complicated arrangement of drawers and compartments; then he clicked together some beads, laid out in a wooden frame connected by a beam and a series of rods, upon which several more beads were lanced.

Impatient, Columbus began to pantomime by rubbing his stomach, and pointing three fingers at his mouth. "We're hungry. Our men need food," he said, indicating his ship. "Is there anything we have that you would barter for?" With a sweeping gesture, he seemed to encompass his whole party.

We don't buy slaves, here. The merchant said, shaking his head. But what about your necklace? Is it gold?

Seeing the merchant pointing at his crucifix, Columbus shielded it by taking the medallion in his fist. "Does no one know Christ in this country? Are all men godless in China?"

Francisco leaned in close to Columbus. "Your men are hungry. The Lord Jesus would feed them if it cost a hundred medallions."

Columbus stood motionless in the mist. Finally, the comptroller spoke. "Señor Columbus, the court will gladly reimburse you for whatever costs are incurred in service of your function."

He unlatched the necklace, handing it to the merchant. The man tested the weight of it in his hand, examined the sheen, and took one arm of the cross into his teeth. Columbus made as though to draw his musket. Francisco held his arm.

This is no good. Not even twenty-four karats. The merchant handed back the medallion, and turned his attention to the next customer.

Columbus stared down at the lump of gold in his hand.

The last entry into Columbus' journal reads: "The natives of this land appear to have no religion. If we could Christianize them, they would make good servants. With fifty men, I could conquer the whole of them and govern them as I pleased."

This account of Columbus' voyage, written by Bartolome de las Casas, is the only extant record to attempt to construct the events leading up to the Shanghai mutiny. It is offered as one explanation 
of why the continents eventually ceased contact, and how Europe came to be called "New America," and why children in China celebrate Columbus Day by giving each other fake gold crosses.

Suggestions for Class Discussion: What would the effect have been if the first contact between New America and China had been made by sages and diplomats rather than merchants? Why did Columbus believe that paradise could be found in the middle of the ocean? If Columbus were successful in subduing China and populating our land with Christians, how would our lives be different? Who would want to live there? 